\title{
Culture of Religious Moderation Through the Actualization of Islamic Education Wasatiyyah to Improve Religious Reconnection and Tolerance in Indonesia
}

\author{
Mohammad Ahyan Yusuf Sya'bani ${ }^{1}$ \\ ${ }^{I}$ Department of Islamic Education, University of Muhammadiyah Gresik \\ *Corresponding author email: ahyanyusuf@umg.ac.id
}

\begin{abstract}
Many issues and actions reflect the behavior of terrorism, extremism, radicalism, intolerance, understanding takfiri (happy to worry), and unilateral truth claims, and so on. This makes the nation-state necessary to seek solutions and prevention (preventive/anticipatory) one of which is to inaugurate the religious behavior that is tolerant, inclusive, and moderate. It can be seen from the viewpoint of religion, especially Islam to give the concept of Islamic Wasatiyyah through good and faithful religious moderation behavior. Therefore, it is crucial to research the actualization of Wasatiyyah Islamic values through religious moderation to improve the harmony and tolerance of religious people in Indonesia. The purpose of this research is to know the meaning and concept of Islamic Wasațiyyah (religious moderation) in the form of value and know the strategy and method of actualization of Islamic Education values Wasatiyyah (religious moderation) in increasing the harmony and tolerance of religious people in Indonesia. This research uses qualitative methods that belong to literature research. The data collection uses techniques with literature and the documentation analyzed by heuristic analysis methods, verification, interpretation, and synthesis. The results of the study showed that the culture of religious moderation possible to create by Islamic education Wasațiyyah. It constructed of tolerance, moderate, inclusive, anti-violence, justice, mutual assistance, harmony, and equal in the way of an accommodating education system to increase the unity among religious people in Indonesia.
\end{abstract}

Keywords: Islam, Wasatiyyah, Tolerance

\section{INTRODUCTION}

Islam is a religion that emphasizes the harmony of all beings. If in the context of teaching, this is better known by the concept of Rahmah (compassion). This Rahmah should create all peace, justice, and order in life. Through the implementation of Rahmah concept, Islam is also expressed the concept of wasatiyyah (moderate) which serves to ground the values of wisdom in the realm of locality and the life of religious people, especially in Indonesia. It can view from the influx of Islam into the archipelago, it is proven historically, Islam entered with a peaceful path and developed so rapidly and rooted strongly in the joints of people's lives in this country.

Teaching on humanity that has existed in Islam, at least conceptualized as Islām rahmatan li al'álamìn (being mercy to the universe), ummatan wasahiyyan (moderate or moderate people), and khaira ummah (the best people) are the basis for the establishment of Islamic behavior and attitudes that are inclusive, tolerant, humanist, and always spread peace $^{1}$ and benefit for the creation of harmony and tolerance in the lives of religious people in Indonesia.
These three teachings in Islam are important to be realized given Indonesia as a great country and nation with its ethnic, ethnic, religious, cultural, racial, and even sociological language ${ }^{2}$. The existence of comfort zones with excellence and diversity in this nation and country in the form of Natural Resources (SDA) and Human Resources (HR) opens up opportunities for all forms of conflict and strife that are the result of egocentrism and egosector attitudes. This is evidenced by various events published through information media, mass/print media, and online media describing the symptoms of national disintegration, terrorism, the radicalism of thought and movement, to the events of criminality in the social structure of society.

Because of the various national issues experienced by this country, it is necessary to be centered on the formulation of Islam wasatiyyah as moderation in religion, nationality, and state so that these problems can be minimized or stopped for the sake of maintaining the integrity of the country and the nation. Based on various descriptions of the background, it can be formulated several problems in this study namely re-uncovering the concept of 
Islam wasatiyyah (religious moderation) and efforts to re-actualization Islamic values wasatiyyah to increase harmony and tolerance of religious people in Indonesia especially through the education process on a national scale.

Furthermore, this research is intended to know the meaning and concept of Islam wasatiyyah (religious moderation) in the form of a value and know the strategies and methods (ways) of realization of Islamic values wasatiyyah (religious moderation) in improving harmony and tolerance of religious people in Indonesia. The process of studying the results of the research relevant to this study has been conducted. But from the results of the study there are still difference in terms of the object of the study, the results and conclusions of the study.

Some of the results of the research that has been studied, namely the research conducted by M. Basir Syam by choosing the title Islam Wasahiyah in Sociology Perspective resulting in Islam wasatiyyah is Islam rahmatan li al-'ālamīn to spread moderate, justice, tolerance, and openness as exemplified by the Prophet Muhammad SAW ${ }^{3}$. Sociologically, this has been done and exemplified by the Prophet (PBUH) in socio-politically when leading the city of Medina. Not only that, his socio-political attitudes were demonstrated by uniting all ethnicities, religions, and tribes, practicing tolerant, moderate, and just behavior to realize the endowed city of Medina.

Then if studying research by Sigit Priatmoko on Confirming Wasathiyah Islam through the Conception of cross-religious Dialogue in Madrasah $^{4}$, then obtained results show there has not been much cross-religious dialogue cultivation in madrasah environment. The culture of crossreligious dialogue to uplift Islam wasatiyyah in madrassa by using multi-religious and interreligious paradigms in educating about religion.

The Islamic wasatiyyah viewpoint introduced in madrassa environments has its method to be instilled in it. This happens because madrasah one of the environment and condition dominated by students with concrete and objectified thinking characteristics. Teachers as educators in madrassa neighborhoods have a central role to re-edify wasahiyah Islam to its students.

There is other research on the Development of PAI (Islamic Religion Education) Insightful Islamic Wasatiyah Learning conducted by Kasinyo and
Tastin ${ }^{5}$ obtaining results in the form of learning PAI (Islamic Education) insightful Islamic wasahiyyah conducted using a contextual scientific approach with the aim that students can realize the teachings of their religion and the existence of other religious teachings, be able to understand the religions of others, always participate in activities involving the role of other religions, and develop the potential of diversity to be able to see the realities of other religions.

The method of this research uses qualitative research methods to examine a descriptive literacy to uncover a problem or event as it is. The results of the study are emphasized in an objective description of the actual state of the object studied ${ }^{6}$. The various data collected in this study come from books on Islam wasatiyyah and religious moderation as the main sources, then also take from various journals, articles, papers, magazines, and other research results relevant to the focus and study of this research. The approach in this study uses a grounded theory approach to bring up and find theories (combined theoretical explanations) ${ }^{7}$ to realize Islamic values wasatiyyah to increase harmony and tolerance of religious people in Indonesia.

The data sources in this study are divided into two, namely: the first is primary source, the source directly related to the main discussion theme in this study, namely the book Religious Moderation by the Ministry of Religious Affairs published in 2019, the book titled Wasatiyyah: Islamic Insight on Religious Moderation by M. Quraish Shihab published in 2019, and all books on Islam wasahiyyah. Secondary sources are all documents, archives, magazines and research reports as well as manuscripts and writings related to the concept of Wasatiyyah Islam and religious moderation. The data collection techniques in this study are two kinds. The first is literature, all data sources either primary or Islamic-focused sources wasatiyyah and moderation religious beliefs are gathered into one. Similarly, data relevant to the focus of this research study will be selected and collected into one.

Second, documentation is a way of collecting data through written relics in the form of archives and also books on theoretical opinions, evidence or other books related to the matter of investigation. The documented data is then selected and classified by the focus of wasatiyyah Islamic studies and religious moderation. All data that has been 
classified according to the focus of the study is done data analysis with: first, heuristic analysis method that collects all the necessary data sources. These resources can be written, spoken, audiovisual, primary and secondary ${ }^{8}$. The focus of this research is only on the collection of data on Wasatiyyah Islam and religious moderation; second, the verification analysis method is to select all the data sources that have been found. Data selection and verification are done by selecting the data according to the focus of this research study.

Third, the method of interpretation analysis is to provide an interpretation of Islamic wasatiyyah data and religious moderation that has been obtained during the study so that it becomes a chronological ${ }^{9}$ sequence of events; fourth, the synthesis analysis method is the writing process in the form of research results. The last step in data analysis is to create synthesis as a form of research results that have been obtained.

\section{URGENCY OF ISLAM WASATIYYAH}

Islamic teachings are a substantial dimension obtained through the source of the textually of the teachings namely the Qur'an and Hadith as well as the contextually of the two sources in the reality of life. Thus, the concept of Islamic wasatiyyah was born on a contemplative study of the content of the Holy Qur'an namely surah al-Baqarah: 143 which states that Muslims should behave in a moderate and inclusive religion. Other languages also mention wasatiyyah as moderate, fair, and inclusive, although the original meaning of wasahiyyah is the one in the middle.

Besides, the term wasahiyyah is still widely found in some other verses of the Quràn, such as surah al-Baqarah: 238 and al-Qalam: $28^{10}$. But at its core, the meaning of wasahiyyah is a reflection of the way Muslims live a life in a societal, political, cultured, national, state, and all other fields. The urgency of Islam wasatiyyah in dampening islamophobic attitudes and mindsets should be realized in the social behavior patterns of Indonesian Islamic society. The reason is that historically Islam came to this archipelago also by way of peace and oriented towards laying the foundation of morality in civil society first. The way of preaching and interacting taught by Islam makes local culture openly accept Islamic $d a^{\prime} w a h$ until now Islam is still firmly rooted in Indonesian society as a whole. The concept of Wasatiyyah Islam and Islamic moderation is teaching that both promotes the principle of harmony of life in religion. Even Islamic moderation has been widely researched and inferred as a characteristic of the Indonesian Muslim way of life for a long time ${ }^{11}$. The world of Indonesian history has also recorded it in the behavior of Indonesians, especially Muslims.

Nusantara culture that is closely related to religiosity and societal society is a reflection that Islam in the Archipelago is a moderate, inclusive, and peaceful Islam. People have become accustomed to living a life that adheres to religious norms, laws, and customs. Thus the presence of Islamic insight wasatiyyah as a solution for the religious social life of Indonesian society as a whole. Open behavior with full awareness of the importance of harmony of life and religious tolerance should be more centered in the discourse of thinking nationally. But not only does it stop as a discourse but manifests in the realities of behavior both social and religious. The moderateness showed by society on a national scale still ceases in the realm of discourse and discussion. The seriousness to apply wasahiyyah values in the dynamics of cross-religious life in Indonesia by the Islamic community especially looks less active or even the concept of wasahiyyah is only seen as interesting to discuss.

Whereas when viewed in the source of Islamic teachings namely the Qur'an, the conception of wasatiyyah is very concerning by being proven to be called the word wasaian which means in the middle has a meaning content that is justice, moderate, inclusive, and many more. Point Islam itself seriously considers wasatiyyah as a special feature of Muslims that must be displayed in the presence of other religious people and the world community. Then Islam itself has made the concept of wasahiyyah as absolute teaching must be applied by its people. The goal is for Muslims to have a central role to set an example for the principle of justice and openness that has not been applied thoroughly in the context of religious and state life.

The two main sources in Islamic teachings namely the Qur'an and al-Hadith have given many guidance and concepts of wasahiyyah teachings either expressly (textually) or implied (contextually), qauliyah or cauniyah. The flexibility of Islamic teachings in both sources states that in the life of this world to prioritize the practice of 
goodness and benefit for everyone. Avoid all forms of violence, strife, conflict, unilateral claims of truth, and hostility as realistic efforts to realize Wasatiyyah Islam become part of the attitude of Indonesian Muslims. Cultural diversity and social life in this country have had a purpose and form in a sublime social system. Islam is present during the life of the People of the Archipelago is to provide religious support and motivation that remains aligned and in line with every local culture. So the teachings of Islam wasatiyyah and culture or tradition there is no separation in particular. Both are the foundation for the implementation of Wasatiyyah Islam and become characteristic of the religious model of Islamic society in Indonesia. Therefore, Islam as a religion and has a variety of different ways of understanding provides a very open space for the method of thinking (ijtihad) to rationalize worship that still seems the only paradigm dogmatic. Rationalization is intended to put worship as religious motivation to realize the principles and values of Islam wasatiyyah in every condition and situation and the social dimension of society.

\section{ISLAM WASATIYYAH IN RELIGIOUS MODERATION CULTURE}

The attitude and nature of religious moderation shown by a Muslim in the life of a nation and a country is the main thing to maintain social, political, national and state stability. There are some of the values found in Islam wasatiyyah namely understanding ${ }^{12}$ the principle of balance in man in the form of physical and spiritual, understanding in man as an individual and social being, acceptance of various diversity and differences.

Furthermore, the next Islamic wasahiyyah value can be to socialize well to all circles despite different religions, ethnicities, tribes, thinking, and so on, balancing the attitude of life materialism and spiritualism, having a medium attitude that is fair and does not feel the right way, being an example in tolerating, witnessing the implementation of fair and intermediate attitudes, being an example and the elect. The conception of Wasatiyyah Islam is important to be focused on addressing the issues and outbreaks of terrorism, radicalism, intolerance, and so on because it has been taught by Islam itself through the letter al-Baqarah verse 143 called وَسنَطًا a people in the middle. This confirms that Islam tends to take a middle ground to solve various problems. Especially when faced with the issue of nationality that has a growing trend, ranging from the threat of terrorism, radicalism, corruption, takfiri understanding, and other criminality. The properties of wasata that should be attached to a Muslim can be an intangible disposition and tolerant attitude, open, fair, give many benefits, appreciate and respect, insightful, moderate, maintain diversity and difference. Thus it is hoped that all threats of national disintegrate, anti-Pancasila, and terrorism can be eliminated easily and precisely.

The peaceful climate and atmosphere of religious life in this country must still be maintained by harmonization of interfaith, ethnic, and racial relations within it. Various conflicts may appear to the surface and even the potential is always there. Anticipating this especially in the context of religious tolerance, it must still be pursued to actualize Islamic values wasatiyyah in the realities of real life. Indonesian Muslims are the most dominant reflection of the nation and the nation, demanding to appear as a reflection of the goodness of their relationship in state life. It is not the opposite of being a preacher of hatred and hostility that is in contrast to the teachings of Islam that are more advocating to do good to anyone even against people of different faiths. Religious differences are not a source of horizontal conflict, while each side presents the principle of wasatiyyah (religious moderation) values to respect each other, be considerable, and uphold the principle of tolerance. The source of the conflict is based more on the ego and interests of each party and the low mutual respect for the difference. The culture of religious moderation is so useful to apply by looking at the potential conflicts that always exist in every second of life. What's more, the culture of Nusantara society is to uphold noble values and glory so that people can feel a safe and peaceful life and away from destructive behavior, hate, and even demean others. This kind of sublime culture that should be kept from being lost is erased by negative influences and tends to favor efforts to undermine the noble values that come from inside and outside this nation.

Tolerances and openness of thought are two things that are the foundation of doing and being moderate (Wasahiyyah), even realistically Nahdlatul ulama's aswaja education model (NU) elevates and implements the values of wasatiyyah in it but with another similar designation that is al-Tawasuth (in the middle $)^{13}$. But the motivation to ground Islam wasatiyyah became the main goal as the purpose of 
Islamic education. The breath and spirit of Wasatiyyah Islam are manifested as the foundation of a movement to educate generations of people who are Islamic but adaptive to local culture. Because the cultural dimension and customs are noble legacies to maintain their existence in response to local wisdom to the negative influences that come from outside. Indonesian society, especially Islam Nusantara, is known as a very strong and strong society in practicing cultural, social, and religious moderation ${ }^{14}$. Culture and religion are a fundamental foundation in religious moderation to develop a tolerant and just attitude of life. All religions in the Archipelago have long experienced and felt the impact of the role played by the Indonesian Islamic community who have contributed a lot in establishing the Unitary State of the Republic of Indonesia (NKRI) and more displays of Islam that are friendly and provide mercy to the universe.

The culture of religious moderation indicates concrete and realistic efforts involving all selfpotential both cognitive, affective, and psychomotor. The estuary is the emergence of a tolerant attitude to all factions, religions, ethnicities, and community groups, has national integrity, and prioritizes nonviolent attitudes, and adaptive to local customs and culture that gives birth to local wisdom. These attitudes can be applied to benefit others and to put aside hostility. The cultural pressure point of moderation also manifests in three moderation attitudes, namely the moderation of thinking, the moderation of movement, and the moderation of deeds. All three of them if applied thoroughly, there will be a culture of religious moderation among fellow people of certain religions and other religions. Harmonization of religious life can be realized easily and firmly rooted in every joint of national and state life. The Indonesian Muslim model should at least be based on the three principles of religious moderation. Indonesian Muslims are different from Muslims in other parts of the world or other religions. The specialty lies in the seriousness of Indonesian Muslims to maintain and practice traditions and cultures that align with Islam, in a way that religion and culture are not disputed but become an interconnected integration.

Indonesian Islamic society does have a peculiarity in thinking religious based on local culture. The result is local wisdom that does not shift culture but instead makes it a foundation of religious thought in addition to the normative foundation of revelation. The moderation of movement in
Indonesia Islamic culture is seen in various social activities that until this second is still played by many Islamic organizations such as Nahdlatul Ulama, Muhammadiyah, and others. The number of social organizations in the community states symbolically that Islam Indonesia is a moderate Islam that is always vying in good for the people and the community. Then the moderation of deeds is also reflected in the embodiment of the attitude displayed by Indonesian Muslims in dealing with other people in the context of Indonesian and humanity that always prioritize the principle of national unity (nationalism) so that the integrity of the nation is realized.

\section{REACUALIZATION OF ISLAMIC EDUCATION WASAHIYYAH IN THE DYNAMICS OF RELIGIOUS TOLERANCE}

Efforts to cultivate open, fair, nonviolent, moderate and other behaviors are an attempt to ground Islam in a variety of ways, one of which is through education. Education is directed to spread the values of tolerance, egalitarianism, moderate, open, and anti-violence to students and society at a general. Students are projected in the future as a credible subject to bring this country into a harmonious religious life and carry a multicultural, multiethnic, and multi-religious spirit. Peaceful and tolerant religious life make this nation and country stronger to be seen by the international community by promoting an Islam that is responsive to humanity and full of peace. Similarly, the potential for life is very diverse in this country as a large nation with a very high level of complexion. Indonesia will be present in the global world order by bringing about the most peaceful religious life.

The implementation of the concept of wasahiyyah devoted to students, manifested into eleven characters of moderate Muslim children shows the result that there are eleven characters of moderate Muslim children among whom have faith, noble nature, advancement, take the middle path towards Islamic teachings, fair, have a tolerant attitude, do not discriminate, prioritize dialogue, dynamic, know good and bad deeds and adaptive to local culture and Islamic heritage ${ }^{15}$. The contextualization of moderate Islam in education requires serious and systematic efforts from educational organizers, both teachers, principals, local communities, and others including parents of 
students to be realized in the form of learning programs oriented towards understanding tolerance, justice, moderate, anti-violence, and impressions in religious life. Certainly given that this country and nation was founded based on social, religious, cultural, language, and ethnic diversity.

Wasatiyyah Islamic education is a solution to overcome the threat of terrorism, national disintegration, demoralization, dehumanization, violence in the name of claiming the truth of a community, religion, or culture, radicalism, disbelief (takfiri), and many more especially related issues of the importance of maintaining harmony and harmony of religious life in this country as well as internationally. There are at least some elements or elements of education that should be considered in applying and realizing Islamic education paradigm Wasahiyyah namely first, starting from a teacher or educator. Teachers in the wasatiyyah-based Islamic education system should be able to present themselves as educators who prioritize fairness, innovative, and consistent in the professions it pursues. But not only that, an educator is very complex in applying the dimensions of wasatiyyah to carry out the task the profession is at least implementing seriously the four competencies that a teacher must have, namely professional competency, pedagogical, personality, social and one competency as a teacher of Islamic religious education, namely leadership competency.

Teachers are at the forefront of creating an Islamic education system and situation. Therefore, one important thing for the sake of the planting of Wasatiyyah Islam through education is that teachers should be moderate towards students in their background issues, academic learning, and developmental psychology during the learning process in school. The moderation that each teacher brings will have a direct impact on the students because the learning atmosphere is increasingly formed a culture of moderation that not only occurs in the sphere of the community but enters in classrooms and of course the school environment.

Furthermore, the second is the material element of teaching and curriculum, preferably formulated to instil Islamic values Wasahiyyah. Every subject in the school, although public or religious subjects must include some principles of values from Islam wasatiyyah such as moderate, fair, tolerant, antiviolence, egalitarian, innovative, civilized, dynamic, consistent, and prioritizing the dialogue process in anticipation of horizontal and vertical conflict in a multicultural and multireligious society. Teaching materials are common in subjects such as mathematics, Indonesian, social sciences and others are given the ultimate goal of each learning about the teaching material which is some value that reflects the behaviour and nature of Wasahiyyah which is to bring about the attitude of justice, innovative, dynamic and others. While in religious subjects such as Islamic Religious Education (PAI) or Fikih, Qur'an, Hadith, Islamic Cultural History, Religious Beliefs, Morals, and even Arabic (for subjects in public school and religious school subjects).

In contrast to the teaching materials in boarding schools whose religious subjects are more detailed not only in the realm of scientific products but until the source of the emergence of the science is also studied, such as 'ulūm al-tafsīr, ushūl al-fiqh, and so on. This type of teaching material if inserted the principle of Islamic values Wasahiyyah in it and the goal of learning achievement is directed to realize the attitude of religious moderation in the principle of Islamic values wasatiyyah, then it will be more supportive to realize Islamic values Wasahiyyah in the educational environment. Teaching materials and curriculum of a school or educational institution should be formatted to accommodate the process of actualization of Islamic values wasahiyyah so that awareness of the importance of moderate behavior (wasatiyyah) can be applied by the Indonesian Islamic community that lives during multiethnic, multicultural, and multi-religious Nusantara society through the planting of awareness of moderate conducted early on in the world of education. Thus, efforts made from an early age through education in the next generation of the nation to bring forth a young generation that is open to insight, happy to behave well to anyone regardless of their background, friendly, and polite in practicing the teachings of religion that it embraces.

The third element of the strategy and method of learning requires following the teaching materials that have been conceptualized to internalize the values of Islam wasahiyyah. This means that if the teaching material contains Islamic values wasahiyyah, then for the material to be conveyed optimally to students should the learning strategies and methods are managed and directed to form and create a learning atmosphere full of a climate of tolerance, mutual respect, upholding the principle of justice, egalitarian towards others, and also anti all forms of violence. For example, learning strategies and methods called discussions and dialogue in the classroom. It provides a symbol of dialectical and dialogue learning and certainly by the principle of moderateness that exists in Islam, in other words, Islam wasatiyyah. Academic openness through 
strategy and learning methods in the form of discussion is a reflection of learning in the Islamic education system paradigm wasatiyyah. The function of Islamic moderation-based learning strategies and methods is to try to change the scientific culture that has been taking place in schools statically and disoriented for the future of dialogue and harmonious religious life.

Then entering the fourth element is the learner. Students in the Wasatiyyah Islamic education system are fostered and guided to understand and actualize the principles of moderate Islam (wasatiyyah) in the process of learning interaction in schools as well as the real-life that exists in society. Various subjects to be taught are supposed to be managed so that students are not only focused on pursuing academic values, but students are motivated and given a stimulus to realize cognitively, affectively and psychomotor the values of religious moderation. Students will initially be given theoretical concepts, such as fission subjects in Islamic Religious Education. Fikih teaching materials about prayer for example, in addition to students, are given training in how to perform prayer properly and their reading, but also students must build mental awareness to establish prayer outside the school environment. Not only that, but the learner is also trained in terms of his affection and psychomotor to be more open mind and his insight in acting that reflects a learner full of awareness to apply the concept of wasatiyyah values in his daily life in school as well as in society.

Awareness of the importance of establishing prayer is not only oriented just an understanding of worship. But in the context of the application of wasahiyyah values, students must be invited and motivated to give birth to a commendable attitude as a result of the prayer that he has done. The commendable or noble attitude that was born as a value of worship that he performed when applied to spread the seeds of goodness to his friend then this has included the existence of the actualization of Islamic values wasahiyyah. A commendable attitude for example in the form of helping his friend who is practised by the learner then he has realized Islamic values wasatiyyah in mutual respect and help attitude regardless of his religious background, ethnicity, race, ethnicity, and also skin color.

The fifth element of the actualization of Islamic values wasatiyyah through efforts in the world of education namely infrastructure and environmental facilities. Even if observed the importance of infrastructure and environmental aspects in an educational perspective can be deepened and studied in depth which is enshrined in verses of the Qur'an as the main source of Islamic teachings. ${ }^{16}$ That man is essentially unable to escape from the circumstances surrounding him, that is, that all that man does is a response from something that arises from a certain condition so that action arises. But all of this remains based on the fact that absolute truth comes from the Almighty God. Thus, the infrastructure and environment in the context of Islamic education wasatiyyah is copyright of conditions and situations that can provide motivation and stimulus for students, educators, and also the development of teaching materials to realize various Islamic values such as the principles of openness, justice, anti-violence and radicalism, do not discriminate based on the social, physical and religious backgrounds it embraces.

The climate of the situation formed through a pattern of behavior spreading goodwill has a positive impact on the sustainability of religious moderation culture in the sphere of education. Including the issue of the function of the building form as the place of the educational process. For example, the availability of places of worship in schools or educational institutions becomes an academicreligious symbol that the institution appreciates a person greatly in embracing and living the teachings of his religion. This is the implementation of wasatiyyah Islamic education. Then the infrastructure in the building used as a place to conduct learning activities must be accommodating and responsive for the educational actors in it, namely teachers, students, and all school residents. For example, infrastructure in the context of Islamic education wasatiyyah namely the availability of learning tools specifically used for students who have physical disabilities. Suppose that students who cannot see perfectly (blind) are provided with reading books with braille to make it easier for them to read because they only have physical or mental limitations. For students who are judged to be slow in the process of receiving the materials taught provided special or additional time so that they can understand something taught quickly and equal the students who can receive above-average teaching materials.

Even up to educational institutions that have multi-storey buildings, there should be special stairs not as usual for people in general or special elevators for students and teachers who have difficulty (physical disabilities) reaching the 
learning room (classroom) upstairs. In such detail, the management of the layout and the provision of all the needs for the success of the educational process in it is a reflection for the implementation and actualization of Islamic education Wasahiyyah. Substantively, Islamic education is a truly accommodating, responsive, and directs students to get used to it early on to behave well with anyone around it. For the good is not only for himself but good will be judged as a positive thing if it is spread to others. All the core elements and elements in education are very large potential or opportunities for the realization of Islamic values wasatiyyah in it. Education is a noble human effort in smartening the next generation so that it can one day take the process of regeneration in the future and the future will be felt benefits for the lives of nations and countries rich in culture, religion, ethnicity, and natural resources. Looking at the living conditions of this nation which is diverse in its ethnicities, religions, and ethnicities, it is important to be realized Islamic education wasatiyyah in educational institutions or institutions. If the educational institution is based on Islam then Islamic education should be able to be realized optimally for the continuity of the educational process in it.

However, if the institution is based on public schools, Islamic education can still be implemented as optimally as possible that involves all the citizens of the school in it to be the pioneer of the spread of good and anti-spreading hatred and hostility towards others in his school because the pioneers of doing good are also the embodiment of the realization of Islamic values wasatiyyah in daily life. Even in non-Islamic-based educational institutions the spirit to apply moderate and justice still gets a very large opportunity to be applied in its educational environment. The motivation for realizing the concept of wasatiyyah (religious moderation) should be preserved. Given the concept of wasatiyyah, although it originated from the teachings of Islam, the nature of the teaching of goodness is for anyone regardless of their social and religious status. So Islam is a religion whose teachings can apply to all beings in this universe and be a mercy to all.

\section{CONCLUSION}

The culture of religious moderation will be realized while synergy with the actualization of Islamic education wasatiyyah. In other words, the urgency of an effort through education in internalizing Wasatiyyah Islam is urgently needed to print future generations who have insight and tolerant attitudes, uphold the principles of justice, anti-violence, inclusive, egalitarian, prioritize the dialogue process on all issues, be moderate in every situation, spread good for anyone, eliminate the seeds of hostility and strife. Islam wasatiyyah if it can be internalized optimally through the concept of education, then the next culture process towards religious moderation will increasingly find its purpose is to minimize or even eliminate all horizontal and vertical conflicts between the ethnic, ethnic, group, and religious. Similarly, the increasing harmony of religious life, tolerance for differences, and increasing harmony between fellow citizens regardless of social and religious background.

The formulation of Wasatiyyah Islamic education is the solution to the conflict of the disintegration of the nation, demoralization of sociable behavior, dehumanization, terrorism, extremism, radicalism, and any form of action that threatens the integrity of unity and unity of the nation as well as the harmony of religious life. The younger generation who are expected to make a great contribution to the unity of the nation and uphold the principle of justice should be able to apply Islamic values early on. Not only the younger generation, but the generation above it should also be able to set an example for the younger generation so that there is an inner connection to help each other in maintaining the integrity of the nation and the harmony of the life of religious people.

\section{ACKNOWLEDGMENTS}

Thanks to all those who have contributed in helping to complete this research. especially to those whose authors are allowed to retrieve data related to the focus of this research. in the end, I hope this research can be useful for all.

\section{REFERENCES}

[1] M. Amin Abdullah, Studi Agama, Normativitas Atau Historisitas? (Yogyakarta: Pustaka Pelajar, 2011), 5. [2] Alwi Shihab, Islam Inklusif: Menuju Sikap Terbuka Dalam Beragama (Bandung: Mizan, 2013), 3. [3] M. Basir Syam, "Islam Wasathiyah dalam Perspektif Sosiologi", Aqidah-

Ta: Jurnal Ilmu Aqidah, Vol. 4, No. 2, (Desember 2018): 211.

[4] Sigit Priatmoko, "Meneguhkan

Islam Wasathiyah Melalui

Pembudayaan Dialog Lintas Agama di 
Madrasah", MIDA: Jurnal Pendidikan Dasar Islam, Vol. 2, No. 1, (Januari 2019): 31.

[5] Kasinyo Harto and Tastin, "Pengembangan Pembelajaran PAI Berwawasan Islam Wasatiyah: Upaya Membangun Sikap Moderasi Beragama Peserta Didik", At-Ta'lim: Media Informasi Pendidikan Islam, Vol. 18, No. 1, (Juni 2019): 105-106. [6] adari Nawawi, Metode Penelitian Bidang Sosial (Yogyakarta: Gadjah Mada University Press, 2013), 31.

[7] J. Corbin and A. Strauss, Basics of Qualitative Research: Techniques and Procedures for Developing Grounded Theory (Thousand Oaks, CA: Sage, 2007), 107.

[8] Kuntowijoyo, Pengantar Ilmu Sejarah (Yogyakarta: Yayasan Bentang Budaya, 2011), 92.

[9] Ibid., 95.

[10] Ragib al-Ashfahany, Mu'jam Mufradaat al-Fazh al-Qur'an (Dar alKatib al- A'raby, 2012), 702.

[11] Siswanto, "Islamic Moderation Values on the Islamic Education Curriculum in Indonesia: A Content Analysis", Jurnal Pendidikan Islam, Vol. 8, No. 1, (Juni 2019): 140. [12] Asep Abdurrohman, "Eksistensi Islam Moderat dalam Perspektif Islam", Rausyan Fikr: Jurnal Pemikiran \& Pencerahan, Vol. 14, No. 1, (Maret 2018): 33

[13] Muhammad Fahmi, "Pendidikan Aswaja NU dalam Konteks Pluralisme", Jurnal Pendidikan Agama Islam (Journal of Islamic Education Studies), Vol. 1, No. 1, (Mei 2013): 171.

[14] Mohamad Salik, "Conserving Moderate Islam in Indonesia An Analysis of Muwafiq's Speech on Online Media", Journal of Indonesian Islam, Vol 13, No. 2, (Desember 2019): 375 .

[15] Asih Andriyati Mardliyah and Syaikhu Rozi, "Karakter Anak Muslim
Moderat; Deskripsi, Ciri-Ciri dan Pengembangannya di Lembaga Pendidikan Anak Usia Dini", Tarbiya Islamia: Jurnal Pendidikan dan Keislaman, Vol. 8, No. 2, (Agustus 2019): 244-245.

[16] Ahmad Yusam Thobroni, "Internalisasi Nilai-Nilai Kesadaran Lingkungan Melalui Pendidikan (Perspektif Al-Qur`an Dan AlHadits)", Jurnal Pendidikan Agama Islam (Journal of Islamic Education Studies), Vol. 2, No. 1, (Mei 2014): 32-33. 